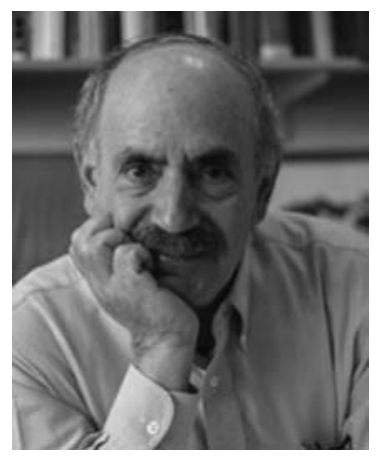

\title{
A Conversation with Robert Weinberg
}

\author{
INTERVIEWER: JAN WITKOWSKI \\ Executive Director, Banbury Center at Cold Spring Harbor Laboratory
}

Robert Weinberg is a Professor of Biology at the Massachusetts Institute of Technology and a Founding Member of the Whitehead Institute for Biomedical Research.

Jan Witkowski: The first Cold Spring Harbor symposium where anything cancer-related appeared in the title was in 1974: the "Tumor Viruses" meeting. That looked very much to do with the biology of viruses rather than much to do with cancer. You were at that meeting.

Dr. Weinberg: Yes. At that time, tumor viruses were studied because they apparently had an interesting way of copying themselves. It was almost incidental that they also caused cancer.

Jan Witkowski: That was only 2 or 3 years after reverse transcriptase?

Dr. Weinberg: Yes, but again, people like me - and there were many others like me-looked at tumor viruses because they would clone genes for you in their own genomes, doing so through their own replicative processes. It was just a sideshow that they also happened to generate tumors in animals. It was almost a distraction for a while.

Jan Witkowski: That changed significantly only 5 years later with the 1979 symposium on viral oncogenes. What led to this transformation in that 5-year period?

Dr. Weinberg: There was the 1975-1976 discovery in the Varmus-Bishop laboratory at the University of California at San Francisco of the astounding fact that a virus that caused sarcomas - connective tissue tumors in chickens - actually had acquired that ability to do so by extracting and remodeling a gene that resided in the normal chicken genome, ostensibly because its role in the normal chicken genome was to help a bird be a bird, therefore having nothing at all to do with the whole process of developing cancer.

Jan Witkowski: It's very hard to put yourself in the mind-set of that period: The idea that it could be a normal cell's genes that, when mutated, could lead to cancer and that viruses could've transduced these.
Dr. Weinberg: Well, it was way out there. It wasn't in the center of everyone's thinking. There was another consequence of that discovery and the discovery that preceded it by several years: that a small number of viral genes could totally reconfigure the whole biology of an infected cell, converting a normal cell into a cancer cell. That had begun to be accepted by that time, but it was hardly obvious. The alternative, more intuitive, hypothesis was that if you asked how many genes needed to be altered in a normal cell to make it into a cancer cell, it might've been dozens. The fact that it was only a single one, at least in these models of virus-induced cancers, totally changed everybody's thinking. Suddenly, one could understand the process of transformation by studying a small number of master genes.

Jan Witkowski: Another important part of that paper was that the src gene could be found in the cells of different species. There was an evolutionary conservation.

Dr. Weinberg: The src gene is in the genomes of all animals, even in the genome of a sponge, which is a very primitive animal. This suggested in a very compelling way that the src gene was important in the biology of a wide spectrum of normal organisms and that its involvement in cancer was only a rare aberration.

Jan Witkowski: Let me read you a quotation from Peter Duesberg: "A critical test for the viral transduction hypothesis would be to isolate a viral transforming gene from a normal cell." So, cue a drumroll for your work where you first isolated a human oncogene.

Dr. Weinberg: Interestingly, the work I got involved in really wasn't that focused on tumor viruses. Much of my interest came from a study by Bruce Ames at the University of California at Berkeley who showed that if you looked at a whole series of chemical carcinogens, their potency in inducing normal cells to become cancer cells was reflected in their ability to damage DNA. In retro-

(C) 2016 Weinberg. This article is distributed under the terms of the Creative Commons Attribution-NonCommercial License, which permits reuse and redistribution, except for commercial purposes, provided that the original author and source are credited. 
spect, maybe the correlation was a little overblown, but at least in my mind - and in the minds of many others, I assume-it suggested the inescapable conclusion that within the DNA of a cancer cell, there lay damaged, mutated genes that were responsible for the abnormal behavior of that cell. That really was the take-home lesson from Ames' work.

Jan Witkowski: In hindsight, it seems obvious that if there is a normal cellular equivalent of $\operatorname{src}$ in a cell, it could undergo mutation that would activate in a way that a viral oncogene could when a virus infects the cell. Ames' work on chemical damage inducing mutations in the cellular gene: That had particular potency for you?

Dr. Weinberg: It did, because already by the mid-1970s retroviral carcinogenesis seemed increasingly implausible as being a major factor in human cancers. On the contrary, chemically induced cancer-for example, cancers induced by cigarette tobacco tar-seemed increasingly to be a more plausible mechanism. Certainly by ' 77 or ' 78 I became convinced that retroviruses were interesting but they were not going to lead us directly to understanding how chemically induced human cancers, and indeed many of the spontaneously arising cancers one sees in humans, arose. I thought there might be a much different causal mechanism.

Jan Witkowski: What strategy did you use to clone ras?

Dr. Weinberg: We had been working on retroviruses, the sort that Howard Temin had first discovered, the sort that Varmus and Bishop had first studied in great detail. We acquired certain laboratory skills, including the ability to take DNA from one cell and put it into another cell experimentally. The DNA that was moved actually entered the second cell and began to function as if it were now an introduced gene and, ultimately, a native gene of the recipient cell.

By 1978, we knew that we could take genomic DNA from a virus-transformed cell and put it into a second cell that then converted from a normal cell into a cancer cell. Maybe, I speculated, we could do the same thing if we extracted DNA from chemically transformed cells that had never experienced a viral infection. To the extent that there was a cancer-inducing gene in such cells, it was with great likelihood a mutated version of a normal gene that somehow had undergone damage or corruption as a consequence of being exposed to, for example, a chemical carcinogen.

That was the thinking. It was way out there, not because it was conceptually complex, but simply because it was quite challenging experimentally. Starting in 1978, a fellow in my laboratory began the onerous task of extracting DNA from chemically transformed cells and introducing that DNA into previously normal cells, converting the latter into cancer cells. After many months of trial and error, he discovered one that could do that. That ended up being the most important set of experiments in my own career because it revealed a simple and obvious truth: In the DNA of chemically transformed cells - and by exten- sion, human cancer cells - there must lie a single gene or a small number of genes responsible for orchestrating the cancerous behavior of the cells in which they resided.

Jan Witkowski: Coming back to the 1991 symposium, we saw the effects of these genes on controlling the cell cycle. At the '94 meeting, Ed Harlow thought that the elucidation of signaling and signal transduction pathways had become a critical aspect of studies of cancer, arising from the ability to clone cancer genes and examine what their proteins were making.

Dr. Weinberg: Underlying all that was the ability acquired in the late 1970 s to actually clone a gene: to extract a single gene from the midst of tens of thousands of genes with which it co-resides within a single cellular genome, the cell being either normal or cancerous. By 1990, we'd also acquired the ability to study the resulting proteins. The earlier work indicated that DNA from a cancer cell could transform a normal cell into a cancer cell but yielded no insight whatsoever into how this introduced cancer gene worked in terms of the mechanisms involved. That is exactly what Ed Harlow was referring to in the early 1990s. He focused on the protein biochemistry of cancer cells, which held the promise of revealing the mechanisms by which cancer-causing genes-oncogenescould transform a normal cell into a cancer cell.

Jan Witkowski: You've continued to be a leader in the field of the mechanisms by which cancers arise.

Dr. Weinberg: By about the year 2000-2001, I came to the conclusion that we understood, in outline, how a normal cell becomes a cancer cell and forms a primary tumor. We still didn't understand the last step of cancer development, which is how cells from the primary tumor seek to form new cancer colonies in distant sites, the process called metastasis. Starting in 2001-2002, people in my laboratory began to look for metastasis-inducing genes that empowered cancer cells from a primary tumor to disseminate to distant sites in the body.

In 2004, we discovered one such gene, which had been studied previously in the context of early fruit fly development. The genes that convert a normal cell into a primary cancer cell - and ultimately a primary cancer cell into one that invades and metastasizes-have been around for six hundred million years, which is about the distance between us and our distant cousins, the fruit flies. We soon learned that the way by which these metastasis genes worked was to take carcinoma cells, which are cells of an epithelial origin, and convert them into cells that are more like connective tissue, or mesenchymal, cells. This conversion process is called the epitheli$\mathrm{al} /$ mesenchymal transition (EMT).

Jan Witkowski: How many genes are involved or needed for the EMT to occur in a cell?

Dr. Weinberg: One can take a primary carcinoma cell and force it to go from the epithelial state to an aggressive mesenchymal state with just a single introduced EMTinducing gene. That cell is now empowered to disseminate to distant sites in the body. That's very satisfying, because 
it means one can trace the ability to spread from one site to another in the body to a small number of master control genes.

That doesn't solve the whole problem, however. It's the major problem of metastasis that has not yet been attacked successfully. Let's say we start out with a breast cancer cell in a primary tumor and it spreads to the brain, or the liver, or the lungs, or the bone marrow. We kind of understand how it does that (i.e., through the workings of the EMT program). The big challenge is to understand how a disseminated cancer cell, which has now inserted itself into a foreign tissue, makes a living once it gets there. Its site of destination, whether it be the brain or the bone marrow, presents a foreign environment to which the disseminated cancer cell is poorly adapted at the moment of its arrival. How does it learn how to make a living there? We don't really understand that.

Jan Witkowski: It'll be interesting to know how many potentially metastatic cells circulate in the blood and how many actually manage to establish themselves. Do you think that's a very small proportion?

Dr. Weinberg: It's a minute proportion. Between 30\% and $35 \%$ of women who are diagnosed with a primary breast cancer already have thousands of micrometastases - small clumps of metastatic cells - in their bone marrow on the day of diagnosis, which means the cancer has already dispatched cells to sites throughout the body. You might think this condition dictates that $30 \%-35 \%$ of breast cancer patients will die from metastatic disease, but it's not true. Only about half of those women who initially come into the clinic with disseminated breast cancer cells will ever develop metastatic breast cancer in their lifetimes. What that means is what you just implied: The chance of a cancer cell that has wandered to a distant tissue successfully founding a colony is minute: maybe one in ten thousand, maybe one in a million. We don't really know the inefficiency of the process.

Jan Witkowski: Do metastases from particular cancers like breast or liver have preferred sites of forming metastases, or are different tissues equally good targets for all cancers?

Dr. Weinberg: The cancer cells originating in certain tissues have a predilection to generate metastases in certain distant sites. For example, prostate cancer typically creates metastases in the bone marrow. Colon cancer typically creates metastases in the liver. Breast cancer is less narrowly specialized, creating metastases in bone marrow, lung, and brain. I suspect, but I can't prove it to you, that the reason why these various primary tumor cells exhibit these tendencies is that, for example, if a prostate cancer cell travels through the circulation into the bone marrow, it is readily able to adapt to the foreign microenvironment in which it's landed, whereas it has a very hard time figuring out how to make a living in the liver. Therefore, even though primary prostate cancer cells get spread all over the body, the metastases that arise are testimonials to the ease or difficulty of these cells to make a living in one or another tissue.

Jan Witkowski: This implies that the microenvironment of the metastatic cell in the prostate presumably has some affinity with the microenvironment in the bone marrow.

Dr. Weinberg: I would agree with that, but articulate it slightly differently. It could be that a prostate cancer cell that was grown in the prostate has to make fewer adaptations when it lands in the bone marrow than the number of adaptations it would need to develop if it were to go to the brain. Of course, I use the word "adaptations" with some reluctance because we don't really know how cancer cells from one site of origin make a living in a distant site in the body.

Jan Witkowski: Would "selection" be a better word than "adaptation"? The prostate cell in the bone marrow struggles to survive but might be able to do two or three divisions or something, and then you get selection by the microenvironment?

Dr. Weinberg: It's both, in Darwinian terms. Let's say that a prostate cancer cell ends up in the bone marrow. It could sit there for days, weeks, or years, trying with little success to make a living there. However, one of its progeny might, through happenstance, eventually acquire the adaptive program to enable that cell to start proliferating in the marrow. It's a model, albeit a crude one, of Darwinian evolution.

Jan Witkowski: Do these findings have implications for dealing with metastases clinically?

Dr. Weinberg: I don't know. I could sell what I've just told you as being the answer to preventing metastases, but I wouldn't want to, because I don't see a clear path leading from these discoveries to useful pathways. Moreover, my own scientific trajectory has always been to try to figure out what's going on mechanistically during cancer pathogenesis without being biased or influenced by how useful it's going to be in the clinic. To my mind, curiosity-driven research is much more likely to turn up unexpected insights that could become useful to someone someday than is a highly directed and focused research program that is attempting, for example, to develop a cure for metastatic disease. 


\section{$\$_{\text {CSH\& }}^{\infty}$ Cold Spring Harbor Symposia SYMPOSIA}

\section{A Conversation with Robert Weinberg}

Cold Spring Harb Symp Quant Biol 2016 81: 357-359 originally published online January 19, 2017

Access the most recent version at doi:10.1101/sqb.2016.81.031625
Creative This article is distributed under the terms of the
Commons http://creativecommons.org/licenses/by-nc/4.0/, which permits reuse and
License redistribution, except for commercial purposes, provided that the original author and source are credited.

Email Alerting Receive free email alerts when new articles cite this article - sign up in Service the box at the top right corner of the article or click here. 